\title{
Economic potential of the agrarian leadership business in the context of effective personnel security and institutional regulation
}

\author{
Olena Nikoliuk \\ Odessa National Academy of Food Technologies \\ Kanatna str. 112, 65039, Odessa \\ Ukraine \\ e-mail: alenavn11@gmail.com \\ Irina Sedikova \\ Odessa National Academy of Food Technologies \\ Kanatna str. 112, 65039, Odessa \\ Ukraine \\ e-mail: $\underline{\text { irina-sedikova@rambler.ru }}$ \\ Svetlana Kalyugina \\ North-Caucasus Federal University \\ Pushkin str.1, 355009, Stavropol \\ Russian Federation \\ e-mail: s.kalyugina@gmail.com
}

\begin{abstract}
The development of economic and social relations in the context of the transition to more specific technical requirements and the enhancement of its economic activity is an important development of the state in the educational phase of development. One of the key aspects of this is the personnel security and institutional regulation.

In this context, one can note that the effective development of the agrarian business is often affected by a number of serious obstacles that require immediate resolution. Technological and technical backwardness of domestic subjects of agrarian business, involved in the production and processing of agricultural products, the ineffectiveness of the existing institutions of agrarian business, the imperfection of regulatory and legal provision, determine the low level of its economic potential and competitiveness on the world stage. Therefore, the research presented in this paper is an actuality of scientific advancement which has a practical understanding for improving the methodological foundations of institutional regulation in particular, on the effective functioning of the appropriate system of renovations in the direction of developing the economic potential that uses the example of the agrarian business sector.
\end{abstract}

\section{Introduction}

The development of modern economic relations makes the issue of the formation of the economic potential of agrarian production under conditions of influence on it of crisis phenomena of the national economy, the influence of globalization factor to be of special importance. Therefore, the issue of institutional regulation of renovations deserves special attention as the necessary progress to intensify the economic potential of domestic agrarian business, which, in turn, affects the quantity and quality of socio-economic development of Ukraine and its effective integration into the European environment (Czyżewski and Smędzik-Ambroży 2015; or NiñoAmézquita et al. 2017). This situation necessitates the strengthening of theoretical and methodological, and practical aspects of the development of strategic imperatives of institutional regulation of the development of the domestic economic potential of agrarian production, the level of which is influenced by society, the state, subjects of market relations and the development of qualitatively new, focused on modern achievements and institutional changes (Moskalenko and Yevsieieva 2015; Lisin et al. 2015; or Budrionytė and Gaižauskas 2018).

A classic approach to the content of the concept "institution" is the interpretation of Douglas North who wrote that "institutions are "the rules of the game» in the society; more formal, institutions are the structures that people impose on their relationships, thus defining the incentives and limitations that outline the boundaries of choice, and in turn, they create the limits of the functioning of the economy and society during that or another period of time" (North 2000). In this sense, we support the viewpoint of Zagursky (2014) concerning the fact that human actions concerning changing the rules and norms are largely caused by the past institutional changes. "Firstly, institutions are created by past institutions. Secondly, generations of people are changing each other as a result of aging and death, but institutions do not die. They become ineffective and eliminate as a result of 
competitive pressure, representing the amount of information in the cells of social and historical memory, playing an important role in the training of future generations " (Zagurskiy 2014).

In this respect, in our view, the integral theorem of Kietzmueller (2012) is appropriate, which says that "the systemic efficiency of the institutions is the higher, the more they maximize the general and minimize the specific transaction costs in the economy" (Kitzmueller 2012; Tireuov et al. 2018). Therefore, when we justify the need for an institutional transformation of the agrarian business, we primarily note its focus on providing collective goods that expand and improve individual goods.

The current state of development of economic relations in Ukraine is characterized by the fact that the processes of self-government intervenes actively developing relevant program documents that focus on behavior prediction and prevention of adverse effects of the environment, maintaining the stability of agrarian business entities. In the management of these processes, the main focus is made on improving the internal structure, improving the proportions and improving the level of industry balance (Strielkowski and Rausser 2013). In addition to the state, the integrated structure of corporations can make free or involuntary influence on the structural design of the system. In agriculture, they can be large consumer cooperatives, associations, holding companies, agrarian financial and industrial groups. By exercising their financial, logistical and managerial potential, they can influence the structure of production, capital, employment parameters, export-import flows, commodity producers' incomes, etc. (Gryshova et al. 2017).

According to Yatsenko (2011), the application of the systematic approach in the research of the agrarian business is complicated by the statistical-economic and technological approaches to its perception and study. There seem to be no adequate understanding of the fact that it is the agricultural activity of the peasant in his own economy - it is not just a set of certain factors of production, not mechanical combination of them. Here the whole is not just a sum of its parts. It is a kind of independent organism that needs assistance in all its manifestations: the use of land, labor, material and technical resources, entrepreneurship, other natural and acquired properties of man, meeting his social and spiritual needs (see Yatsenko 2011).

In the writings of Osovskya (2008) renovation is a prerequisite for maintaining production on the same scale. In the years of the economic crisis, the majority of domestic agrarian enterprises were characterized by a constricted type of reproduction, which was accompanied not only by the decrease of production equipment, but also by the aging of fixed capital. The consolidation of financial resources for the renovation of fixed assets may bring additional economic benefits to the enterprise in the event of legislative consolidation of the provisions of the Amortization Policy Concept, which provides for tax deductions to those entities that have documentary evidence of the investment use of the costs of the depreciation fund. Consequently, it will be beneficial for the enterprise to create the specified fund and ensure its targeted use (Osovska 2008).

According to Bozhko (2013) and Karasyova (2008), renovation is a number of actions aimed at updating the physical and moral depreciation of elements of fixed assets that provide their simple and expanded reproduction. An analysis of renovation can be made due to the factors of growth, retirement, renewal, growth and aggregate reproduction. Taking into account that in the process of updating the material and technical base leasing occupies a significant place, it is proposed to supplement this methodology by the leasing coefficient, which is characterized by the ratio of the fixed assets acquired under the lease for the year introduced to the carrying amount of all fixed assets at the end of the year. Since the leasing form of raising funds in fixed assets is relatively new for domestic enterprises, the application of the proposed ratio will enable to objectively characterize the level of use of leasing (Bozhko 2013; Karasyova 2008).

Taking into account the fundamental contribution of the presented scientists to the formation of theoretical and methodological ideas about the content of economic potential of subjects of agricultural production and the place of institutional regulation of renovations in activating its development, worth noting that the results of the conducted researches are not capable in full measurement changing needs of modern practice effective functioning of the agricultural business. Questions concerning the improvement of theoretical and methodical principles for determining the place of institutional support in implementing strategic imperatives for the development of the economic potential of agrarian production remain unresolved.

Our paper codifies the main views of both domestic and foreign scientists to determine the essence and features of institutional regulation of renovation in the context of ensuring the effective development of the economic potential of agrarian business. An analysis of the current state of development of the economic potential of agrarian business in Ukraine was conducted and identified the main problems of its institutional provision at the present stage of development of the country. It is grounded that the availability of material and technical base of agrarian business in accordance with the existing world standards, raising the level of funded security, expanded reproduction of fixed capital requires the investment of significant investments, which can be achieved by using a complex of institutional measures during the renovations. It was proposed the integrated system of the institutional regulation of renovations, which is focused on the strategic development of domestic agrarian business, which is based on a set of special mechanisms that cover and regulate all processes of agrarian production. Results of the conducted research promote the application of innovative recommendations in the 
direction of implementation of mechanisms of institutional regulation of renovations in order to develop the potential of economic relations of the agricultural business in Ukraine.

\section{Research methodology}

During the formation of conceptual and categorical apparatus used methods for synthesis, analysis, abstraction and complex scientific generalization. Substantiation of approaches to the definition of the content of institutional development of the potential of agricultural production subjects, its components (economic) was carried out using the system-structural method, dialectical generalization, which is based on the principle of systematic, which involves the implementation of the following stages:

1) accentuated the necessity of functioning of the integrated system for developing the potential of agrarian production in Ukraine, including economic ones, in the context of optimality of the use of state institutional adjustment instruments for renovations; defined;

2) key components of the integrated system of economic potential development of agrarian production are

3) it was carried out the grouping of the constituent elements of the system with the coordination of them with existing concepts;

4) the establishment of appropriate contacts and relationships between the elements, substructures and objectives of the system has been conducted.

The use of such methods as historical and logical, induction and deduction facilitated the substantiation of the theoretical and methodological foundations for the development of economic potential in the context of its institutional regulation of renovations. In the process of studying the current state of development of agricultural production and its economic potential, including in the context of institutional performance assessment software used methods of observation, measurement, comparison and consequently cash and analytical.

\section{Results and discussion}

The agrarian sector of Ukraine serves as a key element of the entire national economy, which has significant resources to increase the effectiveness of socio-economic development, the formation of powerful economic potential and food security in general.

Table 1. The indices of production of gross output by the subjects of the agrarian business, $\%$

\begin{tabular}{|c|c|c|c|c|c|c|c|c|c|}
\hline \multirow{4}{*}{ Years } & \multirow{2}{*}{\multicolumn{3}{|c|}{ All categories of farms }} & \multicolumn{6}{|c|}{ Including } \\
\hline & & & & \multicolumn{3}{|c|}{ agricultural enterprises } & \multicolumn{3}{|c|}{ households } \\
\hline & \multirow[b]{2}{*}{$\begin{array}{c}\text { gross } \\
\text { output }\end{array}$} & \multicolumn{2}{|c|}{ from it } & \multirow[b]{2}{*}{$\begin{array}{l}\text { gross } \\
\text { output }\end{array}$} & \multicolumn{2}{|c|}{ from her } & \multirow[b]{2}{*}{$\begin{array}{l}\text { gross } \\
\text { output }\end{array}$} & \multicolumn{2}{|c|}{ from it } \\
\hline & & $\begin{array}{c}\text { plant } \\
\text { growing }\end{array}$ & $\begin{array}{c}\text { animal } \\
\text { husband } \\
\text { ry }\end{array}$ & & $\begin{array}{c}\text { plant } \\
\text { growing }\end{array}$ & $\begin{array}{c}\text { animal } \\
\text { husband } \\
\text { ry }\end{array}$ & & $\begin{array}{c}\text { plant } \\
\text { growing }\end{array}$ & $\begin{array}{c}\text { animal } \\
\text { husbandry }\end{array}$ \\
\hline \multicolumn{10}{|c|}{$1990=100$} \\
\hline 2011 & 69,1 & 86,6 & 50,6 & 47,7 & 57,7 & 33,3 & 119,2 & 207,7 & 75,5 \\
\hline 2012 & 83,0 & 113,2 & 51,3 & 61,5 & 79,7 & 35,4 & 133,4 & 253,4 & 74,1 \\
\hline 2013 & 79,8 & 104,7 & 53,5 & 57,8 & 71,6 & 38,0 & 131,2 & 243,6 & 75,7 \\
\hline 2014 & 90,7 & 123,6 & 56,0 & 70,3 & 90,1 & 41,6 & 138,5 & 264,0 & 76,6 \\
\hline 2015 & 92,6 & 127,6 & 55,8 & 73,1 & 93,9 & 43,1 & 138,5 & 269,0 & 74,0 \\
\hline 2016 & 88,2 & 120,9 & 53,7 & 69,3 & 88,5 & 41,6 & 132,5 & 256,8 & 71,1 \\
\hline \multicolumn{10}{|c|}{ Until the previous year } \\
\hline 2011 & 98,6 & 95,9 & 103,6 & 97,7 & 93,7 & 109,2 & 99,4 & 98,7 & 100,4 \\
\hline 2012 & 120,2 & 130,7 & 101,3 & 129,0 & 138,1 & 106,2 & 111,9 & 122,0 & 98,2 \\
\hline 2013 & 96,1 & 92,6 & 104,3 & 94,0 & 89,8 & 107,5 & 98,4 & 96,2 & 102,1 \\
\hline 2014 & 113,6 & 118,0 & 104,6 & 121,5 & 125,9 & 109,4 & 105,5 & 108,3 & 101,1 \\
\hline 2015 & 102,2 & 103,2 & 99,7 & 104,0 & 104,2 & 103,5 & 100,0 & 101,9 & 96,7 \\
\hline 2016 & 95,2 & 94,7 & 96,3 & 94,8 & 94,2 & 96,5 & 95,7 & 95,5 & 96,1 \\
\hline
\end{tabular}

Source: Ministry of Economic Development and Trade of Ukraine (2016)

The current state of the economic situation of Ukraine needs to create the conditions necessary to ensure the growth of the economic potential of all areas, including agriculture. After all, the higher the level of economic potential of the subjects of agrarian business - the higher the efficiency of their economic activity. Therefore, 
increasing the economic potential of the agrarian business should be a priority task of the agro-industrial policy of Ukraine. The economic potential of domestic agricultural production is determined by the presence of production, technical, personnel and financial conditions in it, which promotes satisfaction of the requirements of specific groups of consumers.

According to (NFP 2016) "... in 2016 compared to 2015 the index of agricultural production was $95.2 \%$ including agricultural enterprises $-94.8 \%$, households $-95.7 \%$. The index of crop production amounted to $94.7 \%$ including agricultural enterprises $-94.2 \%$, households $-95.5 \%$. The index of output of livestock products was $96.3 \%$ including agricultural enterprises $-96.5 \%$, households $-96.1 \%$ "(Table 1$)$.

In 2016, the financial result before the taxation of enterprises from the sale of agricultural products and the provision of services in crop and livestock production amounted to 89.5 billion USD profit (in 2015 - 35.3 billion UAH.), The level of profitability of agricultural production as a whole was $45,7 \%$ (in $2015-26.3 \%$ ).

From the level of providing business entities with working assets, the main means of production, directly depends the effectiveness of their activities and the proportion and the prospects of institutional regulation of renovations are determined. The renewal of fixed assets is carried out at the expense of capital investments, the volumes of which are influenced by inflationary processes (financial fluctuations) that take place both on the state and on the world market. Let's consider the dynamics of capital investments involved in the activity of the agrarian business of Ukraine in 2011-2016.

Along with this, worth noting that there was an increase in the volume of new funds from 2006 to 2015 almost 4 times (from 4.65 to 17,14 billion USD), while the share of new funds in the total amount of investments decreased by $4 \%$ in 2015 relatively to the 2006 figure and, respectively, over the years, amounted to $90 \%$ and $86.1 \%$ (Table 2).

Table 2. Status, gross accumulation and consumption of fixed capital, fixed assets and investments in their acquisition in the agrarian business of Ukraine, 2002-2015

\begin{tabular}{|c|c|c|c|c|c|c|c|c|c|}
\hline \multirow[b]{2}{*}{ Period } & \multirow[b]{2}{*}{$\begin{array}{l}\text { Wear and } \\
\text { tear of } \\
\text { fixed } \\
\text { assets in, \% }\end{array}$} & \multicolumn{3}{|c|}{$\begin{array}{c}\text { Capital stock } \\
\text { in } \% \text { of GDP in the industry }\end{array}$} & \multicolumn{2}{|c|}{$\begin{array}{c}\text { Accrued economic } \\
\text { depreciation }\end{array}$} & \multicolumn{3}{|c|}{$\begin{array}{l}\text { Capital Investments, } \\
\text { billion hryvnias }\end{array}$} \\
\hline & & 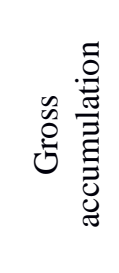 & 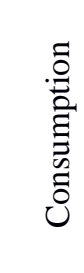 & 导 & 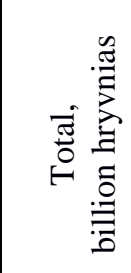 & $\begin{array}{l}0 \\
0 \\
0 \\
0 \\
0\end{array}$ & $\begin{array}{l}\tilde{0} \\
\Xi \\
\Xi \\
0 \\
0 \\
0 \\
\Xi\end{array}$ & 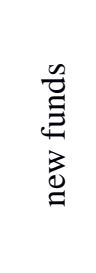 & 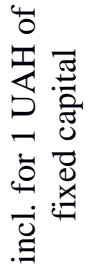 \\
\hline 2002 & 45,0 & - & - & - & 4,30 & 14,5 & - & - & 0,017 \\
\hline 2003 & 47,2 & - & - & - & 4,05 & 13,7 & - & - & 0,022 \\
\hline 2004 & 48,0 & - & - & - & 4,21 & 14,5 & - & - & 0,027 \\
\hline 2005 & 49,3 & - & - & - & 4,99 & 13,4 & - & - & 0,045 \\
\hline 2006 & 49,0 & - & - & - & 6,62 & 16,3 & 0,54 & 4,11 & 0,066 \\
\hline 2007 & 51,5 & 12,5 & 8,9 & 3,6 & 3,84 & 9,3 & 0,85 & 4,45 & 0,097 \\
\hline 2008 & 52,6 & 18,4 & 8,4 & 10,0 & 4,39 & 9,3 & 0,73 & 6,74 & 0,121 \\
\hline 2009 & 61,2 & 14,8 & 5,9 & 6,9 & 5,98 & 9,2 & 0,57 & 10,55 & 0,176 \\
\hline 2010 & 60,0 & 16,2 & 6,0 & 10,1 & 5,79 & 8,8 & 0,48 & 6,10 & 0,091 \\
\hline 2011 & 74,9 & 17,9 & 5,1 & 12,7 & 6,39 & 7,7 & 0,82 & 7,37 & 0,108 \\
\hline 2012 & 32,6 & 13,9 & 5,1 & 8,8 & 6,45 & 9,2 & 1,11 & 11,00 & 0,154 \\
\hline 2013 & 34,6 & 14,7 & 6,6 & 8,1 & 9,46 & 8,4 & 1,69 & 10,12 & 0,141 \\
\hline 2014 & 35,8 & 13,2 & 8,1 & 5,1 & 11,08 & 8,4 & 1,39 & 17,67 & 0,122 \\
\hline 2015 & 38,8 & 9,8 & 6,4 & 3,4 & 11,72 & 7,3 & 2,37 & 14,77 & 0,100 \\
\hline
\end{tabular}

Source: Ministry of Economic Development and Trade of Ukraine (2016)

The share of capital investments per hryvnia of capital, which is turning into agrarian business, tended to increase, but its dynamics was not stable. So, since 2002 to 2009, this indicator has been increasing all the time. After 2009, this figure was wavy. Its highest value was reached in 2012 at the level of 0.154 . Beginning from 2013 there was a decrease in the researched index (in 2015 it was worth 0,100). Let us assume that in agricultural production for the last years studied, the share of capital investments in the total amount of resources involved in this sector is almost $7 \%$. 
Continuing analytical assessments of the development of agrarian production and its economic potential in the format of institutional regulation, we note that in general, the economic component demonstrates positive, especially in the natural sense, but there is a violation of the balancing of socio-economic interests, which are formed in the corresponding system of effects. The research basis for this position became the general economic indicators of the effectiveness of policy and institutional regulation (Table 3), where we include: the number of people employed in the agrarian production; GDP per 1 employed; wage level; gross output and labor productivity; export revenues.

Table 3. The general economic indicators of the effectiveness of institutional regulation of the agrarian business in Ukraine

\begin{tabular}{|c|c|c|c|c|c|c|c|c|}
\hline \multirow{2}{*}{ Indexes } & \multicolumn{8}{|c|}{ Years } \\
\hline & 2000 & 2001 & 2006 & 2011 & 2012 & 2013 & 2014 & 2015 \\
\hline $\begin{array}{l}\text { The number of } \\
\text { people employed in } \\
\text { agrarian } \\
\text { production, } \\
\text { thousand people }\end{array}$ & 4367,0 & 4148,1 & 4005,5 & 3115,6 & 3410,3 & 3308,5 & 3389 & 3091,4 \\
\hline $\begin{array}{l}\% \text { of total } \\
\text { employment }\end{array}$ & 21,6 & 20,8 & 19,4 & 15,4 & 16,8 & 17,2 & 17,5 & 17,1 \\
\hline $\begin{array}{l}\text { GDP at the rate of } 1 \\
\text { employed, UAH }\end{array}$ & 4626,0 & 7088,0 & 10086,0 & 26623,0 & 32244,0 & 34229,0 & 39054,0 & 51923,0 \\
\hline $\begin{array}{l}\text { The average } \\
\text { monthly salary of } \\
\text { one employee, } \\
\text { UAH }\end{array}$ & 111 & 151 & 415 & 1430 & 1800 & 2094 & 2344 & 2556 \\
\hline $\begin{array}{l}\text { In \% to the } \\
\text { economy }\end{array}$ & 48,3 & 48,6 & 51,5 & 63,9 & 68,4 & 68,9 & 71,4 & 73,4 \\
\hline $\begin{array}{l}\text { Gross output at } \\
\text { constant prices, } \\
\text { UAH billions }\end{array}$ & 151,0 & 166,4 & 179,6 & 194,9 & 233,7 & 223,3 & 252,9 & 251,4 \\
\hline $\begin{array}{l}\text { Gross output (labor } \\
\text { productivity) per } 1 \\
\text { employee, UAH }\end{array}$ & 27067 & 34567 & 72622 & 132680 & 165229 & 159679 & 201217 & 227753 \\
\hline $\begin{array}{l}\% \text { of increase to the } \\
\text { previous year }\end{array}$ & $\mathrm{x}$ & 127,7 & 210,1 & 182,7 & 124,5 & 96,6 & 126,0 & 113,2 \\
\hline $\begin{array}{l}\text { Gross output per } 1 \\
\text { hectare of } \\
\text { agricultural land, } \\
\text { UAH }\end{array}$ & 3707 & 4266 & 4710 & 5237 & 6294 & 6015 & 6813 & 7083 \\
\hline $\begin{array}{l}\% \text { of increase to the } \\
\text { previous year }\end{array}$ & $\mathrm{x}$ & 115,1 & 110,4 & 111,2 & 120,2 & 95,6 & 113,3 & 104,0 \\
\hline $\begin{array}{l}\text { Export of agrarian } \\
\text { products, mln }\end{array}$ & 1377 & 1807 & 4305 & 9936 & 12804 & 17881 & 17024 & 16669 \\
\hline US \$ 100, USD & 550,00 & 537,21 & 512,45 & 793,59 & 799,98 & 799,30 & 799,30 & 1188,70 \\
\hline $\begin{array}{l}\text { The export of } \\
\text { agrarian products, } \\
\text { UAH billions }\end{array}$ & 7,6 & 9,7 & 22,1 & 78,9 & 102,4 & 142,9 & 136,1 & 198,1 \\
\hline $\begin{array}{l}\text { The income from } \\
\text { exports per } 1 \\
\text { hectare of } \\
\text { agricultural land, } \\
\text { UAH }\end{array}$ & 186 & 249 & 579 & 2119 & 2759 & 3851 & 3666 & 5582 \\
\hline
\end{tabular}

Source: Ministry of Economic Development and Trade of Ukraine (2016)

Therefore, it can be concluded that the formation of the material and technical basis of agrarian production in accordance with modern world standards, the growth of the level of funded security of the industry, the expanded reproduction of fixed capital requires significant investments that can be achieved through the use of a set of institutional measures in the process of renovation: 
- favorable long-term state lending with low interest in the purchase of agricultural machinery and equipment, construction of livestock complexes, the formation of the main herd of cattle and perennial plantations;

- interest-free state crediting of environmentally friendly agricultural production and introduction of innovative technologies;

- $\quad$ activation of formation of agro-industrial associations, agro-formations, agro parks, etc.

From the foregoing can offer alternative lines of problem-solving support economic potential of agricultural production, such as:

- the search of innovative solutions related to minimizing the costs of harvesting, transportation, storage and processing of agricultural products;

- the introduction of advanced business models primarily based on a network economy;

- the construction of effective models of interaction between science and successful business;

- the development of measures stimulating the processes of cooperation between small and medium-sized farmers;

- the work related to the expansion of existing and the access to new markets for selling the production of Ukrainian agrarians;

- work on improving the quality of training of young specialists in the agrarian sector, including through the exchange of experience with leading economies of the world;

- the reforms the agrarian business of Ukraine (Gryshova and Shestakovska 2017a; 2017b).

In today's Ukraine, at the stage when the overall framework of institutional reforms in the agrarian business, in terms of institutionalization of the laws of the market is practically completed, the question of the increase of efficiency, establishment of models of institutional regulation of renovations based on the need for their approval has become urgent. In this regard, we have conceptually defined and proposed the author's own vision of this process, because the agrarian business is the main, central link, first of all in the development of the countryside as an environment of the life and management (Gryshova et al. 2017). In our opinion, the improvement of institutional regulation of agrarian business should be based on: modernization of the agricultural sector; systemic increase of the competitiveness of production, enterprises; the restriction of market power of large corporate structures (agro-holdings); the formation of community-based rural development; the provision of the state support to innovative initiatives in small and medium business; the establishment of nationally-adapted institutions that take into account the traditions of the Ukrainian people.

The functioning of the agrarian business of Ukraine in the modern globalization conditions depends primarily on the development of its potential. The improvement of its functional organization, rationalization and optimization of the specific structure, the activation of socially responsible business, competitiveness in European markets and the ability to withstand external challenges are directly dependent on the formulation, development and use of strategic guidelines for supporting the economic potential of agrarian businesses through effective institutional regulation.

Fig. 1 presents an integrated system of institutional regulation of strategic development of the agrarian business, which functions through a set of special mechanisms that cover and regulate all processes in the agrarian business. Also, the system of institutional regulation of the development of agrarian production is an integral part of the national system of state regulation, which is formed on the basis of achievements of innovation development, cultural traditions, etc. It is worth noting that the formation of the components of the development of the economic potential of agrarian production requires, first of all, determining their place in the structure of a comprehensive system of institutional regulation. Such research involves consideration of the peculiarities of forming a mechanism for raising the level of economic potential of agrarians on the basis of its institutional regulation, which leads to a more detailed consideration of the peculiarities of the functioning of its components.

Focusing on the constituent mechanisms as part of an integrated system of institutional regulation of production development, we assume that the development process itself is comprehensive, and in the framework of one particular mechanism, it is difficult to find sufficient practical tools for its successful implementation. Among the main conditions for the formation and implementation of the institutional regulation system for the development of agrarian business and its economic potential, which must necessarily be taken into account, are: the conjuncture of the agricultural market in the world; the level of domestic consumption and the price of the product created; infrastructure-servicing component and its functional capabilities and status; the state regulatory policy on the agrarian business and the mechanism of self-regulation; the regional peculiarities of development 
of the agrarian business and rural territorial entities; the innovative and investment components of business development in the countryside.

\section{Conclusions}

Diversification of strategic directions for the development of agrarian business and its economic potential demands from the state and its authorized bodies effective steps to institutionalize the national adaptive norms of behavior of the relevant subjects in the context of ensuring the tasks set and the competitiveness of the national economy. The scientific and methodological principles of the formation of an institutional system for the regulation of agricultural production renovation should be aimed at stimulating the activity of the relevant economic entities in the direction of implementing organizational and economic measures for: the provision of a rational (sufficient to meet the needs of the domestic market and export potential) level of agricultural and food production; active participation of agricultural producers in financing the development of the area; the development of the natural potential of territories and land, which contributes to the integrated development of economic potential.

Grounded provisions for the definition of conceptual provisions of the functioning of the institutional framework for the development of the economic potential of production of agrarian products, which consider features of complex, systematic-synergetic and institutional-cognitive approaches, which consider both external and internal institutional factors and risks of development of economic potential of agricultural production. This approach involves taking into account the relationship between the subjects of market relations, the assessment of the dynamics of institutional development of agrarian business and its potential, determining the role of the state and society in their formation.

\section{Acknowledgements}

This paper was supported by the Russian Foundation for Basic Research (project No. 18-010-00732).

\section{References}

Bozhko VP (2013) Osobennosty yspol'zovanyya reynnovatsyy pry sozdanyy vыsokykh tekhnolohyy v metallurhyy y mashynostroenyy [Features of the use of reinvention in the creation of high technology in metallurgy and mechanical engineering]. Business-Inform 5:134-139.

Budrionytė R, Gaižauskas, L (2018) Historical cost vs fair value in forest accounting: the case of Lithuania. Entrepreneurship and Sustainability Issues 6(1):60-76. doi: 10.9770/jesi.2018.6.1(5)

Czyżewski A, Smędzik-Ambroży K (2015) Specialization and diversification of agricultural production in the light of sustainable development. Journal of International Studies 8(2):63-73. doi: 10.14254/2071-8330.2015/8$2 / 6$

Gryshova IYu, Negodenko VS, Shestakovska TL (2017) The methodological principles of determining the level of performance of the functions of the functions of consumerism. Scientific bulletin of Polissia 3(11):62-67.

Gryshova IYu, Shestakovska TL (2017a) The asymmetry of the resource configuration and its destructive impact on the capitalization of agribusiness. The Scientific Papers of the Legislation Institute of the Verkhovna Rada of Ukraine, 2:128-133.

Gryshova IYu, Shestakovska TL (2017b) The Economic Measurement of Convergence of Institutional Impact on the Sustainability of Development of Domestic Enterprises. Scientific notes of the Institute of Legislation of the Verkhovna Rada of Ukraine 5:61-66.

Karasova NA (2008) Renovatsiya osnovnykh zasobiv sil's'kohospodars'kykh pidpryyemstv v umovakh lizynhu [Renovation of fixed assets of agricultural enterprises under leasing conditions]. Economics: problems of theory and practice 244: 539-546.

Kitzmueller M (2012) Economic Perspectiveson Corporate Social Responsibility. Journal of Economic Literature 50 (1):51-84. doi: 10.1257/jel.50.1.51

Lisin E, Rogalev A, Strielkowski W, Komarov I (2015) Sustainable modernization of the Russian power utilities industry. Sustainability 7(9):11378-11400. doi: 10.3390/su70911378 
Ministry of Economic Development and Trade of Ukraine (2016) The general tendencies of the shadow economy in Ukraine are 2016. http://www.me.gov.ua/ Accessed 28 Aug 2018

Moskalenko V, Yevsieieva I (2015) Effective leadership conflict management in food technology enterprises. International Economics Letters 4(2):91-102. doi: 10.24984/iel.2015.4.2.4

North D (2000) Institution, institutional change and functioning of the economy. Kiev: Fundamentals, 198.

Osovsk HV (2008) Osnovni zasoby v sil's'kohospodars'kykh pidpryyemstvakh Ukrayiny: stan ta shlyakhy pokrashchennya [Fixed assets in agricultural enterprises in Ukraine: status and ways of improvement]. Science and Economics, 4 (2), 304-309.

NFP (2016) Results of activity of financial companies, pawnshops and legal entities (lessors) for 2016. National Commission, which carries out state regulation in the field of financial services markets https://nfp.gov.ua/files/17_Dep_Repetska/FK_4\%20kv_2016.pdf. Accessed 28 Jul 2018

Niño-Amézquita J, Dubrovsky V, Jankurová A (2017) Innovations and competitiveness in regional development: a comparison of Latin America, Europe, and China. Czech Journal of Social Sciences, Business and Economics 6(1):28-36. doi: 10.24984/cjssbe.2017.6.1.4

Strielkowski W, Rausser G (2013) International Labour Migration and Structural Channels: A Case Study of Ukrainian Working Migrants in the Czech Republic. Ekonomicky Casopis 61(10):1034-1052

Tireuov K, Mizanbekova S, Kalykova B, Nurmanbekova G (2018) Towards food security and sustainable development through enhancing efficiency of grain industry. Entrepreneurship and Sustainability Issues 6(1): 446-455. doi: 10.9770/jesi.2018.6.1(27)

Ushakov D, Bandurin V, Bandurin A (2017) Taxation regime as a factor of mutually intergrated macroeconomic systems' dynamics. Montenegrin Journal of Economics 13(1):171-179. doi: 10.14254/1800-5845/2017.13-1.12

Yatsenko O (2011) Methodological instruments of polyfunctional competitiveness evaluation (on the example of agriculture). The Advanced Science 1:30-35

Zagurskiy O (2014) Main trends in the development of arostegui market of Ukraine. Economics and management: problems of science and practice: Collection of scientific articles. Nürnberg, Deutschland, 1: Verlag SWG imex GmbH, pp. 78-82. 